\title{
SARS-CoV-2 and Exposure to Pollution of the Population Near an Industrial Area in the Metropolitan Region in São Paulo State, Brazil
}

Maria Angela Zaccarelli-Marino ( $\sim$ mangelazaccarelli@yahoo.com.br)

Faculdade de Medicina do ABC https://orcid.org/0000-0003-1448-7609

Thalles Balderi

Santa Paula Hospital: Hospital Santa Paula

Felipe Crepaldi

Faculdade de Medicina da Fundacao do ABC: Faculdade de Medicina do ABC

\section{Rudá Alessi}

Faculdade de Medicina do ABC

Marco Martins

Harvard Medical School

\section{Research Article}

Keywords: SARS-CoV-2, atmospheric pollution, inflammation, autoimmune, Metropolitan Region, Brazil

Posted Date: June 24th, 2021

DOI: https://doi.org/10.21203/rs.3.rs-471704/v1

License: (c) (i) This work is licensed under a Creative Commons Attribution 4.0 International License. Read Full License

Version of Record: A version of this preprint was published at Fortune Journal of Health Sciences on January 1st, 2022. See the published version at https://doi.org/10.26502/fjhs.046. 


\section{Abstract}

Industrial installations close to residential areas could cause health risks. Our objectives are to evaluate the interaction between pre-existing conditions (i.e., rhinitis, sinusitis, pharyngitis, obstructive pulmonary diseases (OPDs), conjunctivitis, dermatitis and primary hypothyroidism $(\mathrm{PH})$ ) and a higher risk of complications when infected with SARS-CoV-2 in residents exposed to long-term air pollutants. With a focus on the area affected by the Capuava Petrochemical Complex (CPC) (Region 1) and combining the AERMOD dispersion model with the Weather Research Forecast (WRF) (2016), we evaluated the Greater $A B C$ region, Brazil. The concentrations of the nitrogen dioxide $\left(\mathrm{NO}_{2}\right)$, carbon monoxide $(\mathrm{CO})$, particulate matter (PM10), sulfur dioxide ( $\left.\mathrm{SO}_{2}\right)$ and volatile organic compounds (VOCs) were analyzed in 2017 and these data were correlated with data obtained in a survey of 2004 residents $8-72$ years of age of both sexes; 1002 (Region 1), and 1002 of them reside within the areas surrounding various industrial areas (Region 2). SARS-CoV-2 cases were collected from the Greater ABC region. Region 1 showed higher average concentrations of all pollutants analyzed. Among the 2004 total residents, there were significant differences between Region 1 and Region 2 in the incidence of cases of rhinitis, sinusitis, pharyngitis, OPDs, conjunctivitis, dermatitis and $\mathrm{PH}$ demonstrating that there is a higher incidence of the evaluated diseases in residents who live closer to the CPC. Compared with residents with these diseases, the residents of Region 1 had a higher relative risk of complications when infected with SARS-CoV-2 than did the residents of Region 2.

\section{Introduction}

Industrial installations close to residential areas, together with unfavorable topographic conditions for the dispersion of pollutants, could cause health risks (Ribeiro and Assunção 2001). The health risks associated with residing near petrochemical industrial complexes represent a critical concern due to potential air pollution emissions. Metropolitan regions are important for public health because of the large number of people living in them, and the air pollution levels in metropolitan regions are usually higher than those in other areas. Industrial plants can increase the concentrations of hazardous substances in surrounding areas and cause respiratory symptoms among residents (Zhang et al. 2010). Exposure to air pollution has been associated with compromised pulmonary immune defense mechanisms in both animals and humans (Billionnet et al. 2012; Stieb et al. 2012).

In the last decade, associations between exposure to air pollution and acute health outcomes have been demonstrated in a number of studies (Burnett et al. 1998; Lin et al. 2005; Stieb et al. 2008, 2009; Turneret al. 2011; Villeneuve et al. 2013), and air pollution also increases morbidity, especially in individuals with asthma and/or chronic obstructive pulmonary disease (COPD) (Burnett et al. 1998; Lin et al. 2005; Stieb et al. 2009). A study conducted in Spain used the International Study on Asthma and Allergies in Children's questionnaire to survey the population. They observed a higher prevalence of nocturnal cough among children (aged 6-7 years) and adolescents (aged 13-14 years) who lived within a petrochemical industrial complex in Tarragona than among children and adolescents who lived in areas of the country in which no petrochemical complexes were located (Rovira et al. 2014). 
Since coronavirus disease 2019 (COVID-19) emerged in Wuhan, China in December 2019 (Li et al. 2020), the epidemic caused by severe acute respiratory syndrome coronavirus 2 (SARS-CoV-2), which causes clusters of severe respiratory illness (Huang et al. 2020), has rapidly developed into a pandemic. A rapid and robust response by the global scientific community has described many essential aspects of SARSCoV-2 transmission and its natural history (Backer et al. 2020; Bi et al. 2020; Chan et al. 2020; Chen et al. 2020; Lauer et al. 2020), but critical questions remain (Bi et al. 2020).

The World Health Organization (WHO) has defined this new syndrome using the acronym COVID-19 for Coronavirus Disease 2019 (WHO 2020). At the beginning of April 2020, marked differences in the rate of transmission and in the mortality associated with outbreaks of COVID-19 in different countries were noted. Early studies concluded that the risk factors associated with the development of the disease are older age (Wu et al. 2020 a), history of smoking (Liu et al. 2020), and heart disease (Shi et al. 2020).

Subsequently, the number of infected people increased rapidly, and a month later, the outbreak had developed into a national crisis, with infected individuals diagnosed all over the country (Chan et al. 2020).

As of June 16,2020, there were 7,941,791 confirmed cases of COVID-19 and 434,796 deaths worldwide and 867,624 confirmed cases of COVID-19 and 43,332 deaths in Brazil (Johns Hopkins University 2020; World Health Organization Coronavirus Disease (COVID-19) 2020).

COVID-19 has been associated with high rates of infection and lethality, especially in patients with comorbidities (Kakodkar et al. 2020). It is characterized by fever, cough, fatigue, shortness of breath, pneumonia, and other respiratory tract symptoms (Chen et al. 2020; Wang et al. 2020 a) and, in many cases, progresses to death.

Chronic obstructive pulmonary disease (COPD) is one of the leading causes of morbidity and mortality in high- and low-income countries and represents a significant public health burden worldwide (Liu et al. 2016). In the United States, COPD affects over $6.5 \%$ of adults, is the third leading cause of death, and incurs 700,000 inpatient stays, 1.5 million emergency room visits, and USD 32 billion in cost annually (Ford et al. 2015).

In the 1960s, the prevalence of asthma and allergic diseases began to increase worldwide. Currently, more than 300 million people are affected by these diseases (Litonjua and Weiss 2007).

The association between air pollution and respiratory infections has been a matter of public health concern in recent years (Su et al. 2019); however, both public and scientific interest has heightened since the outbreak of the coronavirus disease 2019 (COVID-19) pandemic (Lewis 2020).

Petroleum processing can emit various organic compounds that can threaten human health (Godoi et al. 2013). Petrochemical industrial complexes (PICs) generate various air pollutants such as volatile organic compounds (VOCs), sulfur dioxide $\left(\mathrm{SO}_{2}\right)$, particulate matter (PM), and nitrogen oxides ( $\mathrm{NOx}$ ) (Rodríguez 
et al. 2004; Wichmann et al. 2009; Tanyanont and Vichit-Vadakan 2012; Hsu et al. 2018; Omidvarborna et al. 2018).

VOCs are organic compounds containing one or more carbon atoms; they have very high vapor pressure and readily evaporate into the atmosphere at room temperature. Some examples include acetone, benzene, ethylene glycol, formaldehyde, methylene chloride, perchloroethylene, toluene, xylene, and 1,3butadiene (Minnesota Department of Health 2010).

High $\mathrm{NO}_{2}$ concentrations are significantly associated with respiratory mortality (Chen et al. 2007; Hoek et al. 2013) and also generate harmful secondary pollutants such as nitric acid $\left(\mathrm{HNO}_{3}\right)$ and ozone $\left(\mathrm{O}_{3}\right)$ (Khoder 2002).

The question of whether COVID-19 can be spread by airborne transmission has been asked both in the scientific community and by the general public since the arrival of the virus. Similar to fine particulate matter (PM2.5), viruses are among the inhalable biological particles that may be airborne. Recent studies have shown that viruses become airborne through sneezing and coughing and that they may be dispersed further as they commingle with PM2.5 (Frontera et al. 2020).

Coarse particulate matter (PM10-2.5) consists of aerodynamically inhalable particles between $10 \mu \mathrm{m}$ and $2.5 \mu \mathrm{m}$ in size. Such particles are generally found near roadways and dust-generating industries. They are considered to be of regulatory interest because they may penetrate up to the level of the lower respiratory tract and the portion of the lung in which gas exchange occurs (Frontera et al. 2020).

There are few epidemiologic studies that relate air pollution and chemical industries to rhinitis, sinusitis, pharyngitis and obstructive pulmonary diseases (OPDs) such as asthma and COPD. Studies in South America have identified associations between residential proximity to a petrochemical plant and asthma, rhinitis, cough and wheezing (Wichmann et al. 2009; Moraes et al. 2010).

Previous studies have found that air pollution is a risk factor for respiratory infection because it carries microorganisms and affects the body's immunity (Zhu et al. 2020). Furthermore, recent studies suggest that the cause of death of many COVID-19 patients is related to cytokine storm syndrome (Guo et al. 2020; Mehta et al. 2020). In this syndrome, which is also known as hypercytokinemia, uncontrolled release of proinflammatory cytokines occurs (Tisoncik et al. 2012). It is a severe reaction of the immune system that leads to a chain of destructive processes in the body that can end in death.

São Paulo State (SP), the most populous and industrialized state in Brazil, has approximately 45 million inhabitants and 7,012 industries (IBGE 2016 a). Our previous studies (Zaccarelli-Marino 2012; ZaccarelliMarino et al. 2016, 2019) involved subjects living in a densely populated area of SP surrounding the Capuava Petrochemical Complex (CPC). We reported primary hypothyroidism (PH) (Zaccarelli-Marino et al. 2016, 2019) and an increase in the incidence of chronic autoimmune thyroiditis (CAT) over the years (Zaccarelli-Marino 2012) and showed evidence that iodine should not be considered the agent responsible for autoimmune thyropathies in Santo André (Marino et al. 2009). Some of the results of the 
current study have been previously reported in the form of an abstract and poster presented at the ABC University Medical Congress (Zacarelli-Marino et al. 2016a, b, 2017a, b, 2018a, b).

\section{Objective}

The objective of this study was to evaluate the interaction between pre-existing conditions (i.e., rhinitis, sinusitis, pharyngitis, obstructive pulmonary diseases such as asthma and chronic obstructive pulmonary disease, conjunctivitis, dermatitis and primary hypothyroidism) and a higher risk of complications when infected with SARS-CoV-2 in residents exposed to long-term air pollutants.

\section{Methods}

\section{Study Population and Data Collection}

This is a cohort study. We evaluated residents living in the area close to the Capuava Petrochemical Complex (CPC) (Fig. 1) in the Greater ABC region from July 2003 through June 2005.

The residents were divided into two groups ( $A$ and $B$ ) based on their proximity to the industrial areas; those who were considered nonexposed (not including a consideration of ambient air pollution) lived in the surroundings of a different industrial area, mainly steel industries in which no petroleum byproducts are manufactured.

The research population was defined after the purpose of this study had been explained to the participants. Prior to data collection, written informed consent was obtained (where appropriate, from the father or mother of the participant or from another responsible person), and authorization for this realization was obtained from the residents.

The data collection consisted of obtaining information on the residents, and a home-based questionnaire was administered to participating residents 8-72 years of age of both sexes who had lived in the area since 2004. The survey was developed and applied by the authors of this study.

Group A comprised 1002 residents, males and females, living in the surroundings of the CPC. This industrial area was named Region 1 and is occupied by 14 industries that produce polyethylene and polypropylene from naphtha distillation as well as various intermediary substances that are used as raw materials in the manufacture of other products. The area is located on the boundaries of Santo André, Mauá and São Paulo (located $0.5 \mathrm{~km}, 1.0 \mathrm{~km}$, and $2.0 \mathrm{~km}$ from the CPC, respectively) in the State of São Paulo (SP), Brazil.

Group B comprised 1002 residents, males and females, living in the surroundings of various industrial areas; these industrial areas harbor mainly steel industries that generate no petroleum byproducts. The area occupied by Group B is located on the boundaries of Santo André, São Bernardo do Campo, and São Caetano do Sul $(7.5 \mathrm{~km}, 8.0 \mathrm{~km}$, and $8.5 \mathrm{~km}$ from Region 1, respectively) in SP, Brazil. This industrial area was named Region 2, and the residents of this region were treated as the control group. 
Information on the city's population density was obtained from the Brazilian Institute of Geography and Statistics (IBGE) (IBGE 2016 b). Regions 1 and 2 were each divided into five cities; 334 residents were evaluated according to their distance from the CPC.

Each resident had lived in the same home in either Region 1 or Region 2 for more than 10 years, and the controls were matched to the participants with respect to their social and economic situations. The socioeconomic conditions of the participants were evaluated through the questionnaire. The residents were selected based on their personal reporting of similar salaries and social habits (these residents do not have the economic means to move far from the polluted areas).

The residents were considered adults if they were at least 18 years of age, and children and adolescents were under the age of 18 . When the residents were children or adolescents, the questions were presented to their parents or to the person(s) responsible for the children.

The visits occurred once in each house; to guarantee maximal participation, we included weekends as a time for visits.

During the study period (2003-2005), there was no preselection of residents from Regions 1 or 2, and only spontaneous answers were considered.

The inclusion criteria were age between 8 and 72 years and having lived in the same house in either Region 1 or Region 2 for more than 10 years. Residents who worked at the CPC were excluded.

Written questionnaires (WQs) have been widely used in epidemiologic studies. The International Study of Asthma and Allergies in Childhood (ISAAC) WQ has been previously validated by a comprehensive study (Vanna et al. 2001).

The ISAAC was an important milestone among epidemiological studies on the prevalence of asthma and allergic illnesses in children and adolescents. The ISAAC was designed to evaluate the prevalence of asthma and allergic problems in children in different parts of the world using the standard method (selfadministered written questionnaire and/or video questionnaire (Asher et al. 1995; ISAAC 1998)).

The written questionnaire (WQ) self-application of ISAAC was the more utilized instrument due to its ease of understanding, low cost, and independence of a trained interviewer (Asher et al. 1995; ISAAC 1998).

The questionnaire "The International Study of Asthma and Allergies in Childhood (ISAAC)" is an important epidemiological survey instrument established in 1991 to investigate asthma, rhinitis, and eczema in adolescents. ISAAC for nasal symptoms was chosen for the epidemiological diagnosis of rhinitis in children and adolescents; it included questions about sneezing, coryza, watery eyes, and itchy eyes (Vanna et al. 2001).

The European Community Respiratory Health Survey II (ECRHS II) was chosen for the epidemiological diagnosis of asthma; it includes questions about the prevalence of wheezing, coughing, panting, previous 
diagnoses, and use of medication for the treatment of asthma. It is also used to determine the incidence of allergic diseases, asthma, and reduced pulmonary function and how ambient factors may be associated with allergic diseases and low pulmonary function (Jarvis and Burney 2002).

The survey respondents were asked their names (initials), age (years), sex (male, female), address and time at local residency, profession and education (adults), education (children and adolescents), and questions about their social and economic situation (adults) and medical history. Rhinitis was investigated through questions based on the same questionnaire: symptoms of sneezing, coryza, watery eyes, itchy eyes, nasal itching, rhinorrhea, blocked nose, cough, sputum production, shortness of breath and rhinitis. All of the symptoms were evaluated in children, adolescents, and adults. Sinusitis was investigated through questions about frontal headache or pain in the jaw region, posterior secretion, watery eyes, itchy eyes and sinusitis; pharyngitis was investigated through questions regarding oropharyngeal pain, scratchiness in the throat, and difficulty swallowing, and OPDs such as asthma and COPD were investigated through questions based on the questionnaire. OPD was based on personal reporting of symptoms such as cough, sputum production and shortness of breath, chest wheezing, and asthma or COPD.

Responses regarding rhinitis, sinusitis, pharyngitis, and OPDs such as asthma and COPD were only considered positive when the patient had been diagnosed and treated by a doctor and had been prescribed medication to treat these pathologies.

We selected only residents who presented with OPD with asthma and COPD and took medications for these pulmonary pathologies. Individuals who were taking medication that could interfere with this study, including those undergoing treatment for other otorhinolaryngological and pulmonary pathologies, were excluded. Individuals with a history of smoking or who suffered from other otorhinolaryngological pathologies, emphysema, bronchiectasis, lung surgery, or other lung diseases were also excluded.

Conjunctivitis was based on personal reports of signs and symptoms such as pink or red color in the white part of the eye, watery eyes, itchiness, a gritty feeling in the eye, irritation and/or burning sensation in the eye, pain in the eye, and photophobia.

The response for conjunctivitis was only considered positive when its diagnosis and treatment had been performed by a physician. We selected only residents presenting with conjunctivitis who were taking medications for this pathology.

Individuals who were taking medication to treat other eye diseases or who had a history of smoking, eye surgery, viral conjunctivitis, or bacterial infection of the eye were excluded.

Dermatitis was based on personal reports of symptoms such as redness, swelling, intense itching, and skin lesions such as red bumps, blisters, and pustules. The response to dermatitis was only considered positive when the residents' information about their diagnosis and treatment was based on a diagnosis 
made by a physician. We selected only residents presenting with dermatitis who were taking medications for this skin pathology.

$\mathrm{PH}$ was evaluated through a questionnaire; we selected only residents presenting with $\mathrm{PH}$ and using thyroid hormone.

\section{SARS-CoV-2 Database}

The number of SARS-CoV-2 cases was collected from each city in the Greater ABC region, a traditionally industrial region of São Paulo State, Brazil, that is part of the São Paulo Metropolitan Region. Five cities were chosen: Santo André, Mauá, the Eastern Region of São Paulo City, São Bernardo do Campo and São Caetano do Sul. All information about SARS-CoV-2 cases was obtained from the five ABC Paulista prefectures, the São Paulo State Health Secretariat, and the Brazilian Ministry of Health (Brazil Ministry of Health 2020; Johns Hopkins University 2020).

\section{Atmospheric Pollutants}

The concentrations of atmospheric pollutants were analyzed in 2017 by numerical simulation with the AERMOD model using meteorological data for the period 2005 to 2009, data on the physical characteristics of the environment (topography and type of land use), and data on pollutant sources (information on the physical characteristics of the sources and their emissions), and these data were correlated with the results of research for the period 2003 to 2005.

AERMOD is a dispersion model developed by the American Meteorological Society (AMS) and the U.S. Environmental Protection Agency (EPA 2008) and made available for public use. The area influenced by atmospheric emissions from the CPC was evaluated using a combination of the AERMOD dispersion model with the Weather Research Forecast (WRF) meteorological model (Kumar et al. 2016).

According to recommendations made by the U.S. Environmental Protection Agency (EPA 2008), the dispersion model should only be applied when 5 years of meteorological data are available. This was accomplished by the fields provided by the WRF model; based on a combination of the meteorological fields with the pollutant emissions data, the concentration isopletes for the regulated pollutants were calculated for the receptor grid (Kumar et al. 2016).

The map of the concentrations of each pollutant was used to identify the hot spots in which the population was more exposed. The only documentation on the building downwash algorithm in AERMOD (American Meteorological Society/U.S. Environmental Protection Agency Regulatory Model), referred to as PRIME (Plume Rise Model Enhancements), refers to the fact that recent field and wind tunnel studies have shown that AERMOD can overpredict concentrations by factors of 2-8 for certain building configurations. While a wind tunnel equivalent building dimension study (EBD) can be conducted to approximately correct the overprediction bias, previous field and wind tunnel studies indicate that there are notable flaws in the PRIME building downwash theory. Although AERMOD/PRIME may provide accurate and unbiased estimates (within a factor of 2) for some building configurations, a major review and update are needed so that accurate estimates can be obtained for other building configurations for 
which significant overpredictions or underpredictions are common due to downwash effects (Petersen et al. 2017).

Two categories of pollutants were analyzed: 1) volatile organic compounds (VOCs), the main source of which is evaporation and leakage from storage tanks; and 2) $\mathrm{NO}_{2}, \mathrm{CO}, \mathrm{PM} 10$, and $\mathrm{SO}_{2}$, which are emitted from chimneys after processing and controlled by São Paulo State legislation (Fig. 1). Although Brazilian legislation does not regulate VOC concentrations, the dispersion curves of VOCs were also analyzed due to the impact of these compounds on health.

\section{Ethical Statement}

This research was approved by the Committee of Ethics in Research of the ABC School of Medicine, SP, Brazil and registered under number 087/2002.

\section{Statistical Analysis}

The likelihood of an individual's developing rhinitis, sinusitis, pharyngitis, obstructive pulmonary diseases such as asthma and chronic obstructive pulmonary disease, conjunctivitis, dermatitis, and primary hypothyroidism in each city were computed for each combination and compared through Wald tests with Bonferroni correction for multiple comparisons.

The association between both regions (Region 1 and Region 2) and diseases (rhinitis, sinusitis, pharyngitis, obstructive pulmonary diseases such as asthma and chronic obstructive pulmonary disease, conjunctivitis, dermatitis, and primary hypothyroidism) was compared by the chi-square test.

The different incidences and relative complication risks of SARS-CoV-2 in association with diseases such as rhinitis, sinusitis, pharyngitis, obstructive pulmonary diseases, conjunctivitis, dermatitis and primary hypothyroidism were compared using the chi-square test.

A polynomial regression that employed the logarithm of the odds of diseases as response and pollutant concentration up to the third degree, along with their interactions, was fitted to the pollutant, which exhibited a consistent trend of increase in concentration with increasing distance from the Capuava Petrochemical Complex (CPC).

\section{Results}

Demographic Characteristics and Determination of Risk Factors for SARS-CoV-2

Among the total residents (2004), there were significant differences in the distributions of individuals with rhinitis, sinusitis, pharyngitis, obstructive pulmonary diseases, conjunctivitis, dermatitis and primary hypothyroidism in Region 1 and Region 2, demonstrating that there is a higher incidence of the evaluated diseases in areas closer to the CPC (Tables 1 and 2). 
Table 2 indicates the population density, the distances of the regions from the $\mathrm{CPC}$, and the number of SARS-CoV-2 deaths per 10,000 cases.

Table 3 displays the number of confirmed cases and deaths due to coronavirus 2 (SARS-CoV-02) in Region 1 and Region 2 according to ABC Paulista prefectures, the São Paulo State Health Secretariat, and the Brazilian Ministry of Health.

\section{Table 1}

Incidence of rhinitis $(\mathrm{RH})$, sinusitis $(\mathrm{SI})$, pharyngitis $(\mathrm{P})$, obstructive pulmonary diseases

(OPDs), conjunctivitis (CO), dermatitis (DER) and primary hypothyroidism (PH) among individuals in Regions 1 and 2 (number of residents in each group = 1,002)

\begin{tabular}{|lllllllll|}
\hline Disease/Relation & RH & SI & P & OPD & CO & DER & PH & TOTAL \\
\hline Region 1 & 395 & 214 & 143 & 156 & 284 & 95 & 324 & 703 \\
\hline Region 2 & 253 & 150 & 76 & 55 & 121 & 58 & 65 & 244 \\
\hline Region 3 & 648 & 364 & 219 & 211 & 405 & 153 & 389 & 947 \\
\hline Ratio Region 1/ Region 3 & 1.56 & 1.43 & 1.88 & 2.84 & 2.35 & 1.64 & 4.98 & 2.88 \\
\hline
\end{tabular}

Table 2

Population densities, distances of regions from the Capuava Petrochemical Complex (CPC), and SARSCoV-2 deaths per 10,000 cases.

\section{Regions and industrial area distance}

Population density $\left(1,000 \mathrm{hab} / \mathrm{km}^{2}\right)$

Industrial area distance $(\mathrm{km})$

SARS-CoV-2 deaths ratio (average/10,000 cases)
Region 1

5.90

1.20

9.7

5.5

Brazilian Institute of Geography and Statistics (IBGE). Coronavirus 2 (SARS-CoV-02) data for five prefectures of ABC Paulista, the São Paulo State Health Secretariat and the Brazilian Ministry of Health

Compared with other residents who reported having had one or more of the evaluated diseases, the residents in Region 1 had a higher relative risk of complications from SARS-CoV-2 than the residents in Region 2 associated with each disease between the regions (Fig. 2). 
Table 3

Number of confirmed cases and deaths relative to coronavirus 2 (SARS-CoV-02) in the cities of Santo André (North), Mauá and eastern São Paulo (Region 1) and Santo André (South), São Bernardo do Campo and São Caetano do Sul (Region 2).

\begin{tabular}{|lllllll|}
\hline Region & Region 1 & \multicolumn{7}{c|}{ Region 2 } \\
\hline Cities & $\begin{array}{l}\text { Santo André } \\
\text { (north) }\end{array}$ & Mauá & $\begin{array}{l}\text { São Paulo* } \\
\text { (east) }\end{array}$ & $\begin{array}{l}\text { Santo André } \\
\text { (south) }\end{array}$ & $\begin{array}{l}\text { São } \\
\text { Bernardo }\end{array}$ & $\begin{array}{l}\text { São } \\
\text { Caetano }\end{array}$ \\
\hline Confirmed & 2,348 & 560 & 2,181 & 2,348 & 3,482 & 1,592 \\
\hline Deaths & 101.5 & 106 & 121 & 105.5 & 274 & 69 \\
\hline $\begin{array}{l}\text { Deaths } \\
\text { ratio/10,000 }\end{array}$ & 4.5 & 18.9 & 5.6 & 4.5 & 7.8 & 4.3 \\
\hline $\begin{array}{l}\text { *São Rafael (São Mateus). Consulted on June 16, 2020, from Coronavirus 2 (SARS-CoV-02) data. Five } \\
\text { prefectures of ABC Paulista, the State Health Secretariat of São Paulo and the Brazilian Ministry of } \\
\text { Health }\end{array}$ & \multicolumn{7}{l}{} \\
\hline
\end{tabular}

Based on the dispersion model, it was possible to estimate the average concentrations of $\mathrm{NO}_{2}, \mathrm{CO}, \mathrm{PM} 10$, $\mathrm{SO}_{2}$ and VOCs for Region 1 and Region 2; these are presented in Table 4.

Table 4

Average concentrations of $\mathrm{NO}_{2}, \mathrm{CO}, \mathrm{PM} 10, \mathrm{SO}_{2}$ and VOCs obtained via the simulated plume along with the distance from the CPC.

\begin{tabular}{|cllllll|}
\hline Location & $\begin{array}{l}\text { Distance } \\
(\mathrm{km})\end{array}$ & $\mathrm{NO}_{2}$ & $\mathrm{CO}$ & $\mathrm{PM} 10$ & $\mathrm{SO}_{2}$ & COVs \\
\cline { 3 - 7 } & $\left(\mu \mathrm{g} / \mathrm{m}^{3}\right)$ & $\left(\mu \mathrm{g} / \mathrm{m}^{3}\right)$ & $\left(\mu \mathrm{g} / \mathrm{m}^{3}\right)$ & $\left(\mu \mathrm{g} / \mathrm{m}^{3}\right)$ & $\left(\mu \mathrm{g} / \mathrm{m}^{3}\right)$ \\
\hline Region 1 & 0.5 & 13.16 & 3.95 & 0.93 & 1.36 & 477.4 \\
\hline 1 & 10.21 & 2.84 & 1.49 & 3.54 & 313.0 \\
\hline 2 & 4.32 & 1.21 & 0.83 & 2.03 & 69.3 \\
\hline Region 2 & 7.5 & 2.15 & 0.69 & 0.19 & 0.34 & 10.5 \\
\hline 8 & 1.82 & 0.59 & 0.16 & 0.33 & 9.2 \\
\hline & 1.5 & 1.84 & 0.59 & 0.16 & 0.31 & 10.3 \\
\hline
\end{tabular}

Region 1, which is closer to the CPC than Region 2, showed higher average concentrations of all pollutants, and we also found differences in the incidence of rhinitis, sinusitis, pharyngitis, obstructive pulmonary diseases, conjunctivitis, dermatitis, and primary hypothyroidism in these two regions (Table 1). 


\section{Discussion}

According to our results, the average concentrations of $\mathrm{NO}_{2}, \mathrm{CO}, \mathrm{PM} 10, \mathrm{SO}_{2}$, and VOCs obtained from the simulated plumes in the cities studied are more significant in areas closer to the CPC (Table 4); this suggests that people living in those areas are more exposed to atmospheric pollutants than people who live far from the petrochemical industries and is consistent with many other studies (Kalabokas et al. 2001; Ragothaman and Anderson 2017; Zaccarelli-Marino et al. 2019).

Our epidemiological surveys were conducted through questionnaires completed from July 2003 to June 2005 by residents living close to the CPC, and our findings showed different incidences of rhinitis, sinusitis, pharyngitis, OPD, conjunctivitis, dermatitis, and PH among a total of 2,004 residents from two different regions (Region 1, which is close to the CPC, and Region 2, which is further away; the respondents included 1,002 residents from each region) (Table 1) and differences in the risk of developing complications from SARS-CoV-2 for the residents of the two regions (Fig. 2).

The concentrations of atmospheric pollutants were analyzed in 2017 using numerical simulations with the AERMOD model using meteorological data for the period from 2005 to 2009, correlating these data with the research done in 2003 to 2005.

Researchers have shown that short-term (hours, days) and long-term (months, years) exposure to PM2.5 is associated with aggravation of asthma and respiratory symptoms and with increased hospital admissions. The adverse health effects of acute (hours to days) and chronic (months to years) exposure to air pollution range from minor irritation of the upper respiratory system to an impact on morbidity in the form of chronic respiratory diseases (asthma, chronic obstructive pulmonary disease (COPD), heart disease, diabetes, hypertension, lung cancer, and death (Burnett et al. 1998; Andersen et al. 2012; Hoffmann et al. 2012; Ko and Hui 2012; Lavigne et al. 2012; Wellenius et al. 2012). More specifically, both acute and chronic exposure to fine particulate matter (PM2.5) has been shown to induce a systemic inflammatory response that can increase the risk of cardiorespiratory morbidity (Stieb et al. 2002; Fink et al. 2012; Nachman and Parker 2012).

PM2.5 consists of particles with median aerodynamic diameter of $2.5 \mu \mathrm{m}$ or less; particles of this size are small enough to invade even the smallest airways, and PM2.5 is associated with adverse health impacts. It generally results from activities that burn fossil fuels, such as operating fuel-powered automotive engines, smelting, and metal processing. The World Health Organization estimated that PM2.5 accounted for 3.1 million deaths and approximately $3.1 \%$ of the global disability-adjusted life years (DALYs) in 2010 (WHO 2013).

Because the petroleum refining and petrochemical industries produce emissions at many stages of their operations, releasing pollutants such as volatile organic compounds, greenhouse gases, and particulate matter (Ragothaman and Anderson 2017), we believe that our findings are related to CPC emissions and that these emissions can significantly decrease the air quality and cause short-term and long-term health impacts for people living near the sites and in the same regions as these industries. 
It is important to know the atmospheric lifetime of VOCs to gain an understanding of the distances they might travel in air. A higher atmospheric lifetime indicates that VOCs can travel a greater distance in the atmosphere, possibly leading to impacts much farther from the emission source (Ragothaman and Anderson 2017).

A wide variety of hazardous chemicals may originate from industrial facilities and other activities to the environment, and these chemicals are harmful to human health and to the environment (Ragothaman and Anderson 2017).

Exposure to air pollution is a known risk factor for asthma and COPD. Individuals with asthma-chronic obstructive pulmonary disease (COPD) overlap syndrome (ACOS) have a more rapid decline in lung function, more frequent exacerbations, and poorer quality of life than those with asthma or COPD alone (To et al. 2016).

Air pollution has indirect systemic effects linked to pro-inflammation and oxidation mechanisms of the lungs, and alterations in immunological processes increase the population's vulnerability to COVID-19 (Contini and Costabile 2020). This is consistent with studies that linked prolonged exposure to air pollution to acute respiratory inflammation, asthma attacks, and death from cardiorespiratory disease (Bates et al. 1990; Schwartz and Dockery 1992; Schwartz et al. 1993; Dockery and Pope 1994), and the possibility of a detrimental effect of air pollution on the prognosis of patients affected by COVID-19 is plausible.

In this study, the relative SARS-CoV-02 risk was higher for residents with rhinitis, sinusitis, pharyngitis, OPD, conjunctivitis, dermatitis, and PH who live closer to the CPC than the risk for residents who do not have these diseases, and these residents displayed increased vulnerability to COVID-19.

Chemical composition influences ecotoxicity, cytotoxicity, and genotoxicity in different ways so that different biological outcomes are expected even in cases of similar number and mass concentrations (Lionetto et al. 2019).

According to the World Health Organization, 41 million people died from noncommunicable diseases (NCDs) worldwide in 2016; this represents 71\% of global deaths (WHO 2018b).

An important cause of these NCDs is industrial air pollution. However, its quantity and composition vary considerably with location. As an example, living in proximity to industrial facilities appears to be an adverse condition. Environmental air pollution contributes to this huge burden through the initiation and promotion of respiratory diseases that are leading causes of death (WHO 2010).

The respiratory tract is one of the parts of the body that is most involved in susceptibility to air pollution. In particular, asthma and COPD had a major impact on the overall worldwide mortality of 4.2 million caused by respiratory diseases in 2008 (WHO 2010). In addition to mortality, the chronic nature of asthma and COPD causes considerable morbidity. In 2012, 6.62 million disability-adjusted life years 
(DALYs) for COPD alone worldwide (WHO 2016) indicated an immense socioeconomic impact of noncommunicable respiratory diseases.

It is well established that individuals with both asthma and COPD and those with asthma - COPD overlap syndrome (ACOS) have more frequent exacerbations, a more rapid decline in lung function, and worse quality of life than individuals with asthma or COPD alone (Kauppi et al. 2011; Miravitlles et al. 2013; Menezes et al. 2014; Papaiwannou et al. 2014).

It is recognized that these conditions or their expression may be influenced by both host and environmental factors (Papaiwannou et al. 2014), including exposure to air pollution.

Research has shown that short-term exposure to $\mathrm{O}_{3}$ is associated with decreased lung function (Rice et al. 2013) and increased hospitalizations for COPD (Medina-Ramón et al. 2006; Ko et al. 2007; Halonen et al. 2010), whereas long-term exposure to $\mathrm{O}_{3}$ is associated with increased respiratory mortality (Jerrett et al. 2009).

Similarly, ground-level ozone $\left(\mathrm{O}_{3}\right)$ or ambient $\mathrm{O}_{3}$ pollution is another major source of air pollution that is also associated with adverse health impacts. The World Health Organization has estimated that $0.1 \%$ of the global DALYs in 2010 can be attributed to $\mathrm{O}_{3}$ exposure (WHO 2011).

Concentrations of $\mathrm{NO}_{2}, \mathrm{CO}, \mathrm{PM} 10, \mathrm{SO}_{2}$, and VOCs that are above the levels specified in the São Paulo air quality standards are present inside the CPC area (Region 1); this can be related to the main signs and symptoms associated with exposure to VOCs, including conjunctival irritation, nose and throat discomfort, allergic skin reactions and dyspnea (EPA 2017). The health effects of VOCs may include eye, nose, and throat irritation, which are also the initial symptoms of COVID-19.

It is essential to know the atmospheric lifetime of VOCs to understand the distances they might travel in the air. A higher atmospheric lifetime indicates that VOCs can travel a greater distance in the atmosphere, possibly impacting areas much farther away from the emission source (Ragothaman and Anderson 2017).

This supports our findings, which showed that the highest levels of VOCs were localized in proximity to the CPC; the levels in the limited area of the CPC were higher than those allowed in the standard for air quality, and increased incidences of rhinitis, sinusitis, pharyngitis, OPD, conjunctivitis, dermatitis, and $\mathrm{PH}$ were found in this area.

According to our results, 143 residents of the region closer to the CPC had pharyngitis, affected by air pollution. In the case of COVID-19, one of the initial symptoms is sore throat. Hence, while sore throat may be the symptom described by the patient, the examination might also reveal nasopharyngitis (Renner et al. 2012), and residents near the CPC should be alert to the risk of COVID-19. 
Brazil is currently among the group of countries with the highest prevalence of allergic rhinitis in the world (Solé et al. 2006). Rhinosinusitis (RS) is characterized by inflammation of the mucosae of the nose and paranasal sinuses, and it is one of the most prevalent disorders of the upper airways.

According to our results, 395 of the residents in the region closer to the CPC had rhinitis, and 214 of them had sinusitis. Due to their high degree of contact with the environment and their limited defense mechanisms, the nasal cavity is one of the organic systems that is most vulnerable to environmental pollutants (Shusterman 1997); that ould tend to increase the vulnerability of this population to COVID-19.

Riediker et al. (2001) found that rhinoconjunctival tissue is sensitive to irritant stimuli during ongoing allergic inflammation; thus, symptoms of allergic rhinoconjunctivitis might be exacerbated in areas with increased levels of air pollutants.

Conjunctivitis is most associated with $\mathrm{O}_{3}$ and $\mathrm{NO}_{2}$ exposure, although $\mathrm{PM} 10$ and $\mathrm{SO}_{2}$ exposure are also correlated (Chang et al. 2012).

Our findings showed that levels of $\mathrm{NO}_{2}, \mathrm{SO}_{2}$, and MP10 that exceeded the levels indicated in the São Paulo air quality standard were localized in proximity to the CPC, where we found more cases of conjunctivitis.

According to our results, 284 of the residents in Region 1 had conjunctivitis. The dense innervation of the ocular surface is extremely sensitive to chemical substances present in the environment. Additionally, human eyes are protected only by a thin layer of tear film, causing them to be very susceptible to the harmful effects of air pollution (Chang et al. 2012; Hong et al. 2016; Fu et al. 2017); if these residents are affected by COVID-19, they could be at higher risk of dangerous eye complications such as retinopathies.

Air pollution is associated with COPD risk (Schikowski et al. 2014).It may also be a factor in transforming asthma into COPD (To et al. 2016).

In this study, 156 residents of the region closer to the CPC had OPD, a condition that is also affected by air pollution. It causes breathlessness in most patients with severe chronic respiratory disease, and in cases of COVID-19, one of the initial symptoms is shortness of breath.

Elevated exposure to $\mathrm{NO}_{2}$ has been associated with hypertension (Shin et al. 2020), heart and cardiovascular diseases (Mann et al. 2002; Pope et al. 2004; Gan et al. 2012), increased rates of hospitalization (Mann et al. 2002), COPD (Euler et al. 1988; Abbey et al. 1993), significant deficits in the development of lung function in children (Gauderman et al. 2000; Avol et al. 2001), reduced lung function or lung injury in adults (Rubenfeld et al. 2005; Bowatte et al. 2017) and diabetes (Shin et al. 2020).

Aging has been associated with a decline in immune defenses and respiratory function that can result in a higher predisposition to respiratory infections. Moreover, among the chronic diseases that affect the elderly population, COPD and asthma can accelerate pulmonary function decline and increase mortality risk (Bentayeb et al. 2012). 
This study shows that the closer participants lived to Region 1, the higher was their risk of death from SARS-CoV-2. This finding should direct the attention of authorities to these populations.

Our findings showed that higher values of $\mathrm{NO}_{2}$ were localized in regions that are in proximity to the CPC. $\mathrm{NO}_{2}$ is a common tracer of air pollution/industrial activity associated with morbidity and mortality (He et al. 2020a, b).

Interdisciplinary research in air pollution and biomedical science can explain how exposure to air pollutants may affect respiratory viral infections, especially in populations already at risk of increased morbidity and mortality rates after infection with respiratory viruses such as SARS-CoV-2.

Exposure to ambient air pollution has recently been implicated in the occurrence and development of autoimmune diseases (Zhao et al. 2019). Autoimmune diseases represent a broad spectrum of disorders characterized by direction of the body's immune responses against its own tissues, resulting in prolonged inflammation and subsequent tissue damage (Zhao et al. 2019).

According to our results, 324 residents of Region 1 had $\mathrm{PH}$. In iodine-sufficient regions, the primary cause of PH is CAT (Dayan and Daniels 1996) and sufficiency of iodine (Marino et al. 2009; de Freitas et al. 2010), and an increase in CAT incidence over the years (Zaccarelli-Marino 2012) was demonstrated in a previous study in Region 1. This finding could draw attention to a risk factor for complications of SARSCoV-2.

Region 1 is unique because its residents live near petrochemical industries, and environmental factors could affect the cases of rhinitis, sinusitis, pharyngitis, OPD, conjunctivitis, and $\mathrm{PH}$. This chronic exposure could be an important contributor to disease and to the higher risk of complications of SARS-CoV-2 in individuals with long-term exposure to air pollutants.

China, where the COVID-19 epidemic started, is severely affected by air pollution (He et al. 2020a, b). An association between short-term exposure to air pollution and COVID-19 infection has also been described for the recent outbreak in China (Zhu et al. 2020).

In recent decades, environmental pollution has increased and air quality has deteriorated in China, mainly due to the country's rapid industrialization (Zhang et al. 2012).

The spatial analysis performed in our study was conducted on a regional scale and combined with the number of deaths that occurred in 66 administrative regions in Italy, Spain, France, and Germany (Ogen 2020). The results showed that of the 4,443 fatality cases, 3,487 (78\%) occurred in five regions located in northern Italy and central Spain. Additionally, the same five regions show the highest $\mathrm{NO}_{2}$ concentrations and downwards airflow, a factor that prevents efficient dispersion of air pollution. These results indicate that long-term exposure to $\mathrm{NO}_{2}$ may be one of the most critical contributors to fatalities caused by the SARS-CoV-2 virus in these regions and perhaps across the whole world (Ogen 2020). 
Since the presence of comorbidities appeared to be a determinant of the etiology and severity of COVID19 symptoms (Chen et al. 2020; Wang et al. 2020b; Wu et al. 2020b), a role of atmospheric pollution in contributing to the high levels of SARS-CoV-2 lethality in northern Italy has been hypothesized (Conticini et al. 2020). In this study, we also show that higher values of $\mathrm{NO}_{2}$ localized in regions in proximity to $\mathrm{CPC}$ could increase the risk of complications in cases of SARS-CoV-2. Air pollution has been termed the "silent killer" by the World Health Organization (WHO 2018a) because its effects often go unnoticed or are not easily measured.

In the present case of SARS-CoV-2, air pollution may facilitate the upsurge of more severe symptoms of the disease of the eye (Chang et al. 2012; Hong et al. 2016; Fu et al. 2017), nose (Shusterman 1997), and throat (Renner et al. 2012), since the virus may travel through the cranial nerves, producing anosmia, ageusia (lack of taste) and possibly retinopathy.

To date, only a limited number of epidemiological studies have actually identified and/or quantified the risk of rhinitis, sinusitis, pharyngitis, OPD, conjunctivitis, dermatitis, and $\mathrm{PH}$. Our study adds evidence that chronic exposure to air pollution may contribute to significant morbidity and that it may contribute to SARS-CoV-2 risk in individuals with preexisting diseases. Better knowledge of the risks posed by exposure to environmental pollutants and SARS-CoV-2 may help us understand and develop preventive strategies to modify the progressive deterioration of lung function that leads to death.

The results of this survey may help to identify susceptible populations that are vulnerable to air pollution and to target preventive strategies.

In addition to the increasing frequency of health service use, we can put forth the hypothesis that individuals living near the CPC, a petrochemical industrial complex, have more symptoms that affect their daily lives and have lower health-related quality of life.

This is a pioneering study related to inflammatory diseases, such as diseases of the upper and lower airways, conjunctivitis, thyroid diseases, and air pollution, and of the impact of these diseases on SARSCoV-2 pandemic infection in a population living in the area surrounding a petrochemical complex in Brazil.

We recommend that patients affected by SARS-CoV-2 be followed up for a long period of time after medical discharge as they may experience consequences of COVID-19 such as vascular complications and pulmonary fibrosis.

Given the magnitude of the problem of air pollution and the major global health problems generated by SARS-CoV-2 and COVID-19, it is essential that any link between air pollution and respiratory, immunological and hormonal diseases be firmly established.

This study has several strengths, including its use of large-scale population-based data covering a 15year period and its use of well-defined geographic regions in residents living in the CPC influence area in 
the Greater $A B C$ region.

The data used in this study were also linked to data on provincial air pollution and to population survey data gathered over a period of multiple years to permit a broader evaluation of the impact of risk factors for SARS-CoV-2 and the development of COVID-19 in the population. The study is also strengthened by its adjustment for important health risk factors, including rhinitis, sinusitis, pharyngitis, OPD, conjunctivitis, dermatitis, and $\mathrm{PH}$, in the analysis of the relationship between air pollution and SARS-CoV-2. Future research in this area should be conducted.

\section{Conclusion}

This study found that residents with rhinitis, sinusitis, pharyngitis, obstructive pulmonary diseases, conjunctivitis, dermatitis, and primary hypothyroidism who were exposed to higher levels of $\mathrm{NO}_{2}, \mathrm{CO}$, $\mathrm{PM} 10, \mathrm{SO}_{2}$, and VOCs had an increased risk of complications from SARS-CoV-2 infection.

Given the asymptomatic characteristic of coronavirus disease in its initial development and the risks posed by its complications, we suggest that SARS-CoV-2 be continuously evaluated in chemical plant employees and in residents living near industrial areas.

\section{Declarations}

\section{Ethics approval and consent to participate}

This research was approved by the Committee of Ethics in Research of the ABC School of Medicine, SP, Brazil, and registered under number 087/2002.

\section{Consent for publication}

The authors declare that they have no competing interests.

\section{Availability of data and materials}

The data generated and used in the analysis of the present study are included in published articles.

\section{Competing interests}

The authors declare that they have no competing interests.

\section{Funding}

This research received no external funding.

\section{Authors' contributions}


Maria Angela Zaccarelli-Marino participated in the design of the study, the acquisition of the data, the interpretation of the results, and the drafting of the manuscript and critically revised the manuscript.

Thalles Zaccarelli Balderi participated in the design of the study, the acquisition of the data, the interpretation of the results, the statistical analysis and the critical revision of the manuscript.

Felipe Mingorance Crepaldi participated in the design of the study, the acquisition of the data, the interpretation of the results and the literature revision.

Rudá Alessi participated in the design of the study and the acquisition of the data and critically revised the manuscript.

Marco Antonio Garcia Martins participated in the design of the study and the interpretation of the results. He also critically revised the manuscript and supervised the study.

All authors have read and approved the final manuscript.

\section{Acknowledgments}

The authors are grateful to the residents of Santo André, Mauá, São Paulo, São Bernardo do Campo and São Caetano do Sul, São Paulo State, Brazil, for their participation and collaboration. We would also like to thank the parents of the younger participants and those responsible for providing the information for their understanding.

The authors are grateful to Professor Maria de Fatima Andrade, PhD, of the University of São Paulo, Department of Atmospheric Sciences of the Institute of Astronomy, Geophysics and Atmospheric Sciences, São Paulo, SP, Brazil, for her support and collaboration regarding atmospheric pollutants.

The authors are grateful to the Public Ministry of São Paulo state, Brazil, for their collaboration, support and trust.

\section{References}

Abbey DE, Colome SD, Mills PK, Burchette R, Beeson WL, Tian Y (1993) Chronic disease associated with long-term concentrations of nitrogen dioxide. J Expo Anal Environ Epidemiol 3:181-202

Andersen ZJ, Raaschou-Nielsen O, Ketzel M, Jensen SS, Hvidberg M, Loft S, Tjønneland A, Overvad K, Sørensen M (2012) Diabetes incidence and long-term exposure to air pollution: a cohort study. Diabetes Care 35:92-98. https://doi.org/10.2337/dc11-1155

Asher MI, Keil U, Anderson HR et al (1995) International Study of Asthma and Allergies in Childhood (ISAAC): rationale and methods. Eur Respir J 8:483-491. https://doi.org/10.1183/09031936.95.08030483 
Avol EL, Gauderman WJ, Tan SM, London SJ, Peters JM (2001) Respiratory effects of relocating to areas of differing air pollution levels. Am J Respir Crit Care Med 164:2067-2072.

https://doi.org/10.1164/ajrccm.164.11.2102005

Backer JA, Klinkenberg D, Wallinga J (2020) Incubation period of 2019 novel coronavirus (2019-nCoV) infections among travellers from Wuhan, China, 20-28 January 2020. Euro Surveill 25:2000062. https://doi.org/10.2807/1560-7917.es.2020.25.5.2000062

Bates DV, Baker-Anderson M, Sizto R (1990) Asthma attack periodicity: a study of hospital emergency visits in Vancouver. Environ Res 51:51-70. https://doi.org/10.1016/s0013-9351(05)80182-3

Bentayeb M, Simoni M, Baiz N, Norback D, Baldacci S, Maio S, Viegi G, Annesi-Maesano I (2012) Adverse respiratory effects of outdoor air pollution in the elderly. Int J Tuberc Lung Dis 16:1149-1161. https://doi.org/10.5588/ijtld.11.0666

Bi Q, Wu Y, Mei S et al (2020) Epidemiology and transmission of COVID-19 in 391 cases and 1286 of their close contacts in Shenzhen, China: a retrospective cohort study. Lancet Infect Dis 20:911-919. https://doi.org/10.1016/S1473-3099(20)30287-5

Billionnet C, Sherrill D, Annesi-Maesano I (2012) Estimating the health effects of exposure to multipollutant mixture. Ann Epidemiol 22:126-141. https://doi.org/10.1016/j.annepidem.2011.11.004

Bowatte G, Erbas B, Lodge CJ et al (2017) Traffic-related air pollution exposure over a 5-year period is associated with increased risk of asthma and poor lung function in middle age. Eur Respir J 50:1602357. https://doi.org/10.1183/13993003.02357-2016

Brazil Ministry of Health (2020) Painel coronavírus. https://covid.saude.gov.br/. Accessed 17 June 2020

Burnett RT, Cakmak S, Brook JR (1998) The effect of the urban ambient air pollution mix on daily mortality rates in 11 Canadian cities. Can J Public Health 89:152-156.

https://doi.org/10.1007/bf03404464

Chan JFW, Yuan S, Kok KH et al (2020) A familial cluster of pneumonia associated with the 2019 novel coronavirus indicating person-to-person transmission: a study of a family cluster. Lancet 395:514-523. https://doi.org/10.1016/S0140-6736(20)30154-9

Chang CJ, Yang HH, Chang CA, Tsai HY (2012) Relationship between air pollution and outpatient visits for nonspecific conjunctivitis. Invest Ophthalmol Vis Sci 53:429-433. https://doi.org/10.1167/iovs.118253

Chen N, Zhou M, Dong X et al (2020) Epidemiological and clinical characteristics of 99 cases of 2019 novel coronavirus pneumonia in Wuhan, China: a descriptive study. Lancet 395:507-513.

https://doi.org/10.1016/S0140-6736(20)30211-7

Page 20/31 
Chen TM, Gokhale J, Shofer S, Kuschner WG (2007) Outdoor air pollution: nitrogen dioxide, sulfur dioxide, and carbon monoxide health effects. Am J Med Sci 333:249-256.

https://doi.org/10.1097/MAJ.0b013e31803b900f

Conticini E, Frediani B, Caro D (2020) Can atmospheric pollution be considered a co-factor in extremely high level of SARS-CoV-2 lethality in Northern Italy? Environ Pollut 261:114465.

https://doi.org/10.1016/j.envpol.2020.114465

Contini D, Costabile F (2020) Does air pollution influence COVID-19 outbreaks? Atmosphere 11:5. https://doi.org/10.3390/atmos11040377

Dayan CM, Daniels GH (1996) Chronic autoimmune thyroiditis. N Engl J Med 335:99-107. https://doi.org/10.1056/nejm199607113350206

de Freitas CU, Campos RAG, Silva MAR, Panachão MR, de Moraes JC, Waissmann W, Roberto Chacra A, Maeda MY, Rodrigues RSM, Belchor JG, Barbosa SO, Santos RT (2010) Can living in the surroundings of a petrochemical complex be a risk factor for autoimmune thyroid disease? Environ Res 110:112-117. https://doi.org/10.1016/j.envres.2009.10.009

Dockery DW, Pope CA (1994) Acute respiratory effects of particulate air pollution. Annu Rev Public Health 15:107-132. https://doi.org/10.1146/annurev.pu.15.050194.000543

EPA (2008) Air emissions factors and quantification. ttnchie1/ap42/ch05/final/c05s01.pdf. Accessed 9 December 2009

EPA 2017 United States Environmental Protection Agency . Indoor Air Quality (IAQ) Technical Overnew of Volatile Organic Compounds.

Fink R, Eržen I, Medved S (2012) Environmentally induced health impacts among elderly with cardiovascular isease. Health Med 6:3841-3849

Ford ES, Murphy LB, Khavdou O, Giles WH, Holt JB, Croft JB (2015) Total and state-specific medical and absenteeism costs of COPD among adults aged $\geq 18$ years in the United States for 2010 and projections through 2020. Chest 147:31-45. https://doi.org/10.1378/chest.14-0972

Frontera A, Cianfanelli L, Vlachos K, Landoni G, Cremona G (2020) Severe air pollution links to higher mortality in COVID-19 patients: the "double-hit" hypothesis. J Infect 81:255-259. https://doi.org/10.1016/j.jinf.2020.05.031

Fu Q, Mo Z, Lyu D, Zhang L, Qin Z, Tang Q, Yin H, Xu P, Wu L, Lou X, Chen Z, Yao K (2017) Air pollution and outpatient visits for conjunctivitis: a case-crossover study in Hangzhou, China. Environ Pollut 231:13441350. https://doi.org/10.1016/j.envpol.2017.08.109 
Gan WQ, Davies HW, Koehoorn M, Brauer M (2012) Association of long-term exposure to community noise and traffic-related air pollution with coronary heart disease mortality. Am J Epidemiol 175:898-906. https://doi.org/10.1093/aje/kwr424

Gauderman WJ, McConnell R, Gilliland F, London S, Thomas D, Avol E, Vora H, Berhane K, Rappaport EB, Lurmann F, Margolis HG, Peters J (2000) Association between air pollution and lung function growth in southern California children. Am J Respir Crit Care Med 162:1383-1390.

https://doi.org/10.1164/ajrccm.162.4.9909096

Godoi RH, Godoi AF, Junior SJG et al (2013) Healthy environment-indoor air quality of Brazilian elementary schools nearby petrochemical industry. Sci Total Environ 463-464:639-646. https://doi.org/10.1016/j.scitotenv.2013.06.043

Guo YR, Cao QD, Hong ZS, Tan YY, Chen SD, Jin HJ, Tan KS, Wang DY, Yan Y (2020) The origin, transmission and clinical therapies on coronavirus disease 2019 (COVID-19) outbreak - an update on the status. Mil Med Res 7:11. https://doi.org/10.1186/s40779-020-00240-0

Halonen Jl, Lanki T, Tiittanen P, Niemi JV, Loh M, Pekkanen J (2010) Ozone and cause-specific cardiorespiratory morbidity and mortality. J Epidemiol Community Health 64:814-820. https://doi.org/10.1136/jech.2009.087106

He L, Zhang S, Hu J, Li Z, Zheng X, Cao Y, Xu G, Yan M, Wu Y (2020a) On-road emission measurements of reactive nitrogen compounds from heavy-duty diesel trucks in China. Environ Pollut 262:114280. https://doi.org/10.1016/j.envpol.2020.114280

He MZ, Kinney PL, Li T, Chen C, Sun Q, Ban J, Wang J, Liu S, Goldsmith J, Kioumourtzoglou MA (2020b) Short- and intermediate-term exposure to $\mathrm{NO}(2)$ and mortality: a multi-county analysis in China. Environ Pollut 261:114165. https://doi.org/10.1016/j.envpol.2020.114165

Hoek G, Krishnan RM, Beelen R, Peters A, Ostro B, Brunekreef B, Kaufman JD (2013) Long-term air pollution exposure and cardio- respiratory mortality: a review. Environ Health 12:43. https://doi.org/10.1186/1476-069X-12-43

Hoffmann B, Luttmann-Gibson $\mathrm{H}$, Cohen A et al (2012) Opposing effects of particle pollution, ozone, and ambient temperature on arterial blood pressure. Environ Health Perspect 120:241-246. https://doi.org/10.1289/ehp.1103647

Hong J, Zhong T, Li H et al (2016) Ambient air pollution, weather changes, and outpatient visits for allergic conjunctivitis: a retrospective registry study. Sci Rep 6:23858. https://doi.org/10.1038/srep23858

Hsu CY, Chiang HC, Shie RH, Ku CH, Lin TY, Chen MJ, Chen NT, Chen YC (2018) Ambient VOCs in residential areas near a large-scale petrochemical complex: spatiotemporal variation, source apportionment and health risk. Environ Pollut 240:95-104. https://doi.org/10.1016/j.envpol.2018.04.076 
Huang C, Wang Y, Li X et al (2020) Clinical features of patients infected with 2019 novel coronavirus in Wuhan, China. Lancet (London, England) 395:497-506. https://doi.org/10.1016/S0140-6736(20)30183-5

IBGE (2016a) Brazilian institute of geography and statistics. http://cidades.ibge.gov.br/painel/painel.php?codmun=35503. Accessed 10 May 2016

IBGE (2016b) Brazilian institute of geography and statistics. http://cidades.ibge.gov.br/painel/painel.php?codmun=355030. Accessed 10 June 2020

ISAAC (1998) Worldwide variation in prevalence of symptoms of asthma, allergic rhinoconjunctivitis, and atopic eczema: ISAAC. The International Study of Asthma and Allergies in Childhood (ISAAC) Steering Committee. Lancet 351:1225-1232. https://doi.org/10.1016/S0140-6736(97)07302-9

Jarvis D, Burney P (2002) The European community respiratory health survey II. Eur Respir J 20:10711079. https://doi.org/10.1183/09031936.02.00046802

Jerrett M, Burnett RT, Pope CA, Ito K, Thurston G, Krewski D, Shi Y, Calle E, Thun M (2009) Long-term ozone exposure and mortality. N Engl J Med 360:1085-1095. https://doi.org/10.1056/NEJMoa0803894

Johns Hopkins University (2020) Coronavirus. http://www.conre3.org.br>portal>coronavirus. Accessed 17 June 2020

Kakodkar P, Kaka N, Baig MN (2020) A comprehensive literature review on the clinical presentation, and management of the pandemic coronavirus disease 2019 (COVID-19). Cureus 12:e7560. https://doi.org/10.7759/cureus.7560

Kalabokas PD, Hatzianestis J, Bartzis JG, Papagiannakopoulos P (2001) Atmospheric concentrations of saturated and aromatic hydrocarbons around a Greek oil refinery. Atmos Environ 35:2545-2555. https://doi.org/10.1016/s1352-2310(00)00423-4

Kauppi P, Kupiainen H, Lindqvist A, Tammilehto L, Kilpeläinen M, Kinnula VL, Haahtela T, Laitinen T (2011) Overlap syndrome of asthma and COPD predicts low quality of life. J Asthma 48:279-285. https://doi.org/10.3109/02770903.2011.555576

Khoder MI (2002) Atmospheric conversion of sulfur dioxide to particulate sulfate and nitrogen dioxide to particulate nitrate and gaseous nitric acid in an urban area. Chemosphere 49:675-684.

https://doi.org/10.1016/s0045-6535(02)00391-0

Ko FWS, Hui DSC (2012) Air pollution and chronic obstructive pulmonary disease. Respirology 17:395401. https://doi.org/10.1111/j.1440-1843.2011.02112.x

Ko FWS, Tam W, Wong TW, Chan DPS, Tung AH, Lai CKW, Hui DSC (2007) Temporal relationship between air pollutants and hospital admissions for chronic obstructive pulmonary disease in Hong Kong. Thorax 62:780-785. https://doi.org/10.1136/thx.2006.076166 
Kumar A, Patil RS, Dikshit AK, Islam S, Kumar R (2016) Evaluation of control strategies for industrial air pollution sources using American Meteorological Society/Environmental Protection Agency Regulatory Model with simulated meteorology by Weather Research and Forecasting Model. J Clean Prod 116:110117. https://doi.org/10.1016/j.jclepro.2015.12.079

Lauer SA, Grantz KH, Bi Q, Jones FK, Zheng Q, Meredith HR, Azman AS, Reich NG, Lessler J (2020) The incubation period of coronavirus disease 2019 (COVID-19) from publicly reported confirmed cases: estimation and application. Ann Intern Med 172:577-582. https://doi.org/10.7326/m20-0504

Lavigne E, Villeneuve PJ, Cakmak S (2012) Air pollution and emergency department visits for asthma in Windsor, Canada. Can J Public Health 103:4-8. https://doi.org/10.1007/bf03404060

Lewis D (2020) Is the coronavirus airborne? Experts can't agree. Nature 580:175. https://doi.org/10.1038/d41586-020-00974-w

Li Q, Guan X, Wu P et al (2020) Early transmission dynamics in Wuhan, China, of novel coronavirusinfected pneumonia. N Engl J Med 382:1199-1207. https://doi.org/10.1056/NEJMoa2001316

Lionetto MG, Guascito MR, Caricato R, Giordano ME, De Bartolomeo AR, Romano MP, Conte M, Dinoi A, Contini D (2019) Correlation of oxidative potential with ecotoxicological and cytotoxicological potential of PM10 at an urban background site in Italy. Atmosphere 10:733.

https://doi.org/10.3390/atmos10120733

Litonjua AA, Weiss ST (2007) Is vitamin D deficiency to blame for the asthma epidemic? J Allergy Clin Immunol 120:1031-1035. https://doi.org/10.1016/j.jaci.2007.08.028

Liu W, Tao ZW, Wang L, Yuan ML, Liu K, Zhou L, Wei S, Deng Y, Liu J, Liu HG, Yang M, Hu Y (2020) Analysis of factors associated with disease outcomes in hospitalized patients with 2019 novel coronavirus disease. Chin Med J (Engl) 133:1032-1038.

https://doi.org/10.1097/cm9.0000000000000775

Liu Y, Yan S, Poh K, Liu S, lyioriobhe E, Sterling DA (2016) Impact of air quality guidelines on COPD sufferers. Int J Chron Obstruct Pulmon Dis 11:839-872. https://doi.org/10.2147/copd.s49378

Mann JK, Tager IB, Lurmann F, Segal M, Quesenberry CP, Jr., Lugg MM, Shan J, Van Den Eeden SK (2002) Air pollution and hospital admissions for ischemic heart disease in persons with congestive heart failure or arrhythmia. Environ Health Perspect 110:1247-1252. https://doi.org/10.1289/ehp.021101247

Marino MA, Martins LC, Esteves RZ, Kasamatsu TS, Maciel RM (2009) Urinary iodine in patients with auto-immune thyroid disorders in Santo André, SP, is comparable to normal controls and has been steady for the last 10 years. Arq Bras Endocrinol Metabol 53:55-63. https://doi.org/10.1590/s0004-

27302009000100009 
Medina-Ramón M, Zanobetti A, Schwartz J (2006) The effect of ozone and PM10 on hospital admissions for pneumonia and chronic obstructive pulmonary disease: a national multicity study. Am J Epidemiol 163:579-588. https://doi.org/10.1093/aje/kwj078

Mehta P, McAuley DF, Brown M, Sanchez E, Tattersall RS, Manson JJ (2020) COVID-19: consider cytokine storm syndromes and immunosuppression. Lancet 395:1033-1034. https://doi.org/10.1016/s01406736(20)30628-0

Menezes AMB, Oca MMD, Pérez-Padilla R, Nadeau G, Wehrmeister FC, Lopez-Varela MV, Muiño A, Jardim JRB, Valdivia G, Tálamo C (2014) Increased risk of exacerbation and hospitalization in subjects with an overlap phenotype: COPD-asthma. Chest 145:297-304. https://doi.org/10.1378/chest.13-0622

Minnesota Department of Health (2010) Volatile organic compounds (VOCs) in your home. http://www.health,state.mn.us/divs/eh/risk/rules/air/index.html

Miravitlles M, Soriano JB, Ancochea J, Muñoz L, Duran-Tauleria E, Sánchez G, Sobradillo V, García-Río F (2013) Characterisation of the overlap COPD-asthma phenotype. Focus on physical activity and health status. Respir Med 107:1053-1060. https://doi.org/10.1016/j.rmed.2013.03.007

Moraes AC, Ignotti E, Netto PA, Jacobson Lda S, Castro H, Hacon Sde S (2010) Wheezing in children and adolescents living next to a petrochemical plant in Rio Grande do Norte, Brazil. J Pediatr 86:337-344. https://doi.org/10.2223/jped.2020

Nachman KE, Parker JD (2012) Exposures to fine particulate air pollution and respiratory outcomes in adults using two national datasets: a cross-sectional study. Environ Health 11:25. https://doi.org/10.1186/1476-069x-11-25

Ogen $\mathrm{Y}$ (2020) Assessing nitrogen dioxide (NO(2)) levels as a contributing factor to coronavirus (COVID19) fatality. Sci Total Environ 726:138605. https://doi.org/10.1016/j.scitotenv.2020.138605

Omidvarborna H, Baawain M, Al-Mamun A (2018) Ambient air quality and exposure assessment study of the Gulf cooperation council countries: a critical review. Sci Total Environ 636:437-448. https://doi.org/10.1016/j.scitotenv.2018.04.296

Papaiwannou A, Zarogoulidis P, Porpodis K et al (2014) Asthma-chronic obstructive pulmonary disease overlap syndrome (ACOS): current literature review. J Thorac Dis 6 Suppl 1:S146-S151. https://doi.org/10.3978/j.issn.2072-1439.2014.03.04

Petersen RL, Guerra SA, Bova AS (2017) Critical review of the building downwash algorithms in AERMOD. J Air Waste Manag Assoc 67:826-835. https://doi.org/10.1080/10962247.2017.1279088 
Pope CA, Burnett RT, Thurston GD, Thun MJ, Calle EE, Krewski D, Godleski JJ (2004) Cardiovascular mortality and long-term exposure to particulate air pollution: epidemiological evidence of general pathophysiological pathways of disease. Circulation 109:71-77.

https://doi.org/10.1161/01.cir.0000108927.80044.7f

Ragothaman A, Anderson W (2017) Air quality impacts of petroleum refining and petrochemical industries. Environments 4:66. https://doi.org/10.3390/environments4030066

Renner B, Mueller CA, Shephard A (2012) Environmental and non-infectious factors in the aetiology of pharyngitis (sore throat). Inflamm Res 61:1041-1052. https://doi.org/10.1007/s00011-012-0540-9

Ribeiro H, Assunção J (2001) Historical overview of air pollution in Sao Paulo metropolitan area, Brazil: influence of mobile sources and related health effects. Department of Environmental Health-University of Sao Paulo, Brazil

Rice MB, Ljungman PL, Wilker EH, Gold DR, Schwartz JD, Koutrakis P, Washko GR, O'Connor GT, Mittleman MA (2013) Short-term exposure to air pollution and lung function in the Framingham Heart Study. Am J Respir Crit Care Med 188:1351-1357. https://doi.org/10.1164/rccm.201308-14140C

Riediker M, Monn C, Koller T, Stahel WA, Wüthrich B (2001) Air pollutants enhance rhinoconjunctivitis symptoms in pollen-allergic individuals. Ann Allergy Asthma Immunol 87:311-318. https://doi.org/10.1016/s1081-1206(10)62246-6

Rodríguez S, Querol X, Alastuey A, Viana MM, Alarcón M, Mantilla E, Ruiz CR (2004) Comparative PM10PM2.5 source contribution study at rural, urban and industrial sites during PM episodes in Eastern Spain. Sci Total Environ 328:95-113. https://doi.org/10.1016/s0048-9697(03)00411-x

Rovira E, Cuadras A, Aguilar X, Esteban L, Borràs-Santos A, Zock JP, Sunyer J (2014) Asthma, respiratory symptoms and lung function in children living near a petrochemical site. Environ Res 133:156-163. https://doi.org/10.1016/j.envres.2014.05.022

Rubenfeld GD, Caldwell E, Peabody E, Weaver J, Martin DP, Neff M, Stern EJ, Hudson LD (2005) Incidence and outcomes of acute lung injury. N Engl J Med 353:1685-1693.

https://doi.org/10.1056/NEJMoa050333

Schikowski T, Adam M, Marcon A et al (2014) Association of ambient air pollution with the prevalence and incidence of COPD. Eur Respir J 44:614-626. https://doi.org/10.1183/09031936.00132213

Schwartz J, Dockery DW (1992) Particulate air pollution and daily mortality in Steubenville, Ohio. Am J Epidemiol 135:12-19. https://doi.org/10.1093/oxfordjournals.aje.a116195

Schwartz J, Slater D, Larson TV, Pierson WE, Koenig JQ (1993) Particulate air pollution and hospital emergency room visits for asthma in Seattle. Am Rev Respir Dis 147:826-831.

https://doi.org/10.1164/ajrccm/147.4.826

Page 26/31 
Shi S, Qin M, Shen B et al (2020) Association of cardiac injury with mortality in hospitalized patients With COVID-19 in Wuhan, China. JAMA Cardiol 5:802-810. https://doi.org/10.1001/jamacardio.2020.0950

Shin S, Bai L, Oiamo TH, Burnett RT, Weichenthal S, Jerrett M, Kwong JC, Goldberg MS, Copes R, Kopp A, Chen $\mathrm{H}$ (2020) Association between road traffic noise and incidence of diabetes mellitus and hypertension in Toronto, Canada: a population-based cohort study. J Am Heart Assoc 9:e013021. https://doi.org/10.1161/jaha.119.013021

Shusterman D (1997) Upper respiratory tract disorders. In: LaDou J (ed) Occupational and environmental medicine. Appleton and Lange, Stanford, CT, pp 291-304

Solé D, Wandalsen GF, Camelo-Nunes IC, Naspitz CK (2006) Prevalence of symptoms of asthma, rhinitis, and atopic eczema among Brazilian children and adolescents identified by the International Study of Asthma and Allergies in Childhood (ISAAC) - Phase 3. J Pediatr (Rio J) 82:341-346. https://doi.org/10.2223/jped.1521

Stieb DM, Chen L, Eshoul M, Judek S (2012) Ambient air pollution, birth weight and preterm birth: a systematic review and meta-analysis. Environ Res 117:100-111.

https://doi.org/10.1016/j.envres.2012.05.007

Stieb DM, Judek S, Burnett RT (2002) Meta-analysis of time-series studies of air pollution and mortality: effects of gases and particles and the influence of cause of death, age, and season. J Air Waste Manag Assoc 52:470-484. https://doi.org/10.1080/10473289.2002.10470794

Su W, Wu X, Geng X, Zhao X, Liu Q, Liu T (2019) The short-term effects of air pollutants on influenza-like illness in Jinan, China. BMC Public Health 19:1319. https://doi.org/10.1186/s12889-019-7607-2

Tanyanont W, Vichit-Vadakan N (2012) Exposure to volatile organic compounds and health risks among residents in an area affected by a petrochemical complex in Rayong, Thailand. Southeast Asian J Trop Med Public Health 43:201-211

Tisoncik JR, Korth MJ, Simmons CP, Farrar J, Martin TR, Katze MG (2012) Into the eye of the cytokine storm. Microbiol Mol Biol Rev 76:16-32. https://doi.org/10.1128/mmbr.05015-11

To T, Zhu J, Larsen K et al (2016) Progression from asthma to chronic obstructive pulmonary disease. Is air pollution a risk factor? Am J Respir Crit Care Med 194:429-438. https://doi.org/10.1164/rccm.201510$19320 \mathrm{C}$

Vanna AT, Yamada E, Arruda LK, Naspitz CK, Solé D (2001) International study of asthma and allergies in childhood: validation of the rhinitis symptom questionnaire and prevalence of rhinitis in schoolchildren in São Paulo, Brazil. Pediatr Allergy Immunol 12:95-101. https://doi.org/10.1034/j.1399-

3038.2001.012002095.x 
Wang D, Hu B, Hu C et al (2020a) Clinical characteristics of 138 hospitalized patients with 2019 novel coronavirus-infected pneumonia in Wuhan, China. JAMA 323:1061-1069.

https://doi.org/10.1001/jama.2020.1585

Wang T, Du Z, Zhu F, Cao Z, An Y, Gao Y, Jiang B (2020b) Comorbidities and multi-organ injuries in the treatment of COVID-19. Lancet 395:e52. https://doi.org/10.1016/s0140-6736(20)30558-4

Wellenius GA, Burger MR, Coull BA, Schwartz J, Suh HH, Koutrakis P, Schlaug G, Gold DR, Mittleman MA (2012) Ambient air pollution and the risk of acute ischemic stroke. Arch Intern Med 172:229-234. https://doi.org/10.1001/archinternmed.2011.732

WHO (2010) Global status report on noncommunicable diseases. WHO, Geneva

WHO (2011) Global burden of diseases. World Health Organization, Geneva

WHO (2013) Health effects of particulate matter. WHO, Geneva

WHO (2016) Ambient air pollution: a global assessment of exposure and burden of disease. WHO, Geneva

WHO (2018a) Air pollution, the invisible killer. WHO, Geneva

WHO (2018b) Noncommunicable diseases. https://www.who.int/news-room/factsheets/detail/noncommunicable-diseases. Accessed 22 January 2020

WHO (2020) WHO Director-General's remarks at the media briefing on 2019-nCoV on 11 February 2020. WHO, Geneva

Wichmann FA, Müller A, Busi LE, Cianni N, Massolo L, Schlink U, Porta A, Sly PD (2009) Increased asthma and respiratory symptoms in children exposed to petrochemical pollution. J Allergy Clin Immunol 123:632-638. https://doi.org/10.1016/j.jaci.2008.09.052

Wu C, Chen X, Cai Y et al (2020a) Risk factors associated with acute respiratory distress syndrome and death in patients with coronavirus disease 2019 pneumonia in Wuhan, China. JAMA Intern Med 180:934943. https://doi.org/10.1001/jamainternmed.2020.0994

Wu F, Zhao S, Yu B et al (2020b) A new coronavirus associated with human respiratory disease in China. Nature 579:265-269. https://doi.org/10.1038/s41586-020-2008-3

Zaccarelli-Marino MA (2012) Chronic autoimmune thyroiditis in industrial areas in Brazil: a 15-year survey. J Clin Immunol 32:1012-1018. https://doi.org/10.1007/s10875-012-9703-2

Zaccarelli-Marino MA, Alessi R, Balderi TZ, Martins MAG (2019) Association between the occurrence of primary hypothyroidism and the exposure of the population near to industrial pollutants in São Paulo State, Brazil. Int J Environ Res Public Health 16:3464. https://doi.org/10.3390/ijerph16183464 
Zaccarelli-Marino MA, André CDS, Singer JM (2016) Overt primary hypothyroidism in an industrial area in São Paulo, Brazil: the impact of public disclosure. Int J Environ Res Public Health 13:1161. https://doi.org/10.3390/ijerph13111161

Zhang J, Mauzerall DL, Zhu T, Liang S, Ezzati M, Remais JV (2010) Environmental health in China: progress towards clean air and safe water. Lancet 375:1110-1119. https://doi.org/10.1016/s01406736(10)60062-1

Zhang XY, Wang YQ, Niu T, Zhang XC, Gong SL, Zhang YM, Sun JY (2012) Atmospheric aerosol compositions in China: spatial/temporal variability, chemical signature, regional haze distribution and comparisons with global aerosols \&quot; published in Atmos. Atmos Chem Phys 12:779-799. https://doi.org/10.5194/acp-12-6273-2012

Zhao CN, Xu Z, Wu GC et al (2019) Emerging role of air pollution in autoimmune diseases. Autoimmun Rev 18:607-614. https://doi.org/10.1016/j.autrev.2018.12.010

Zhu Y, Xie J, Huang F, Cao L (2020) Association between short-term exposure to air pollution and COVID19 infection: evidence from China. Sci Total Environ 727:138704. https://doi.org/10.1016/j.scitotenv.2020.138704

\section{Figures}




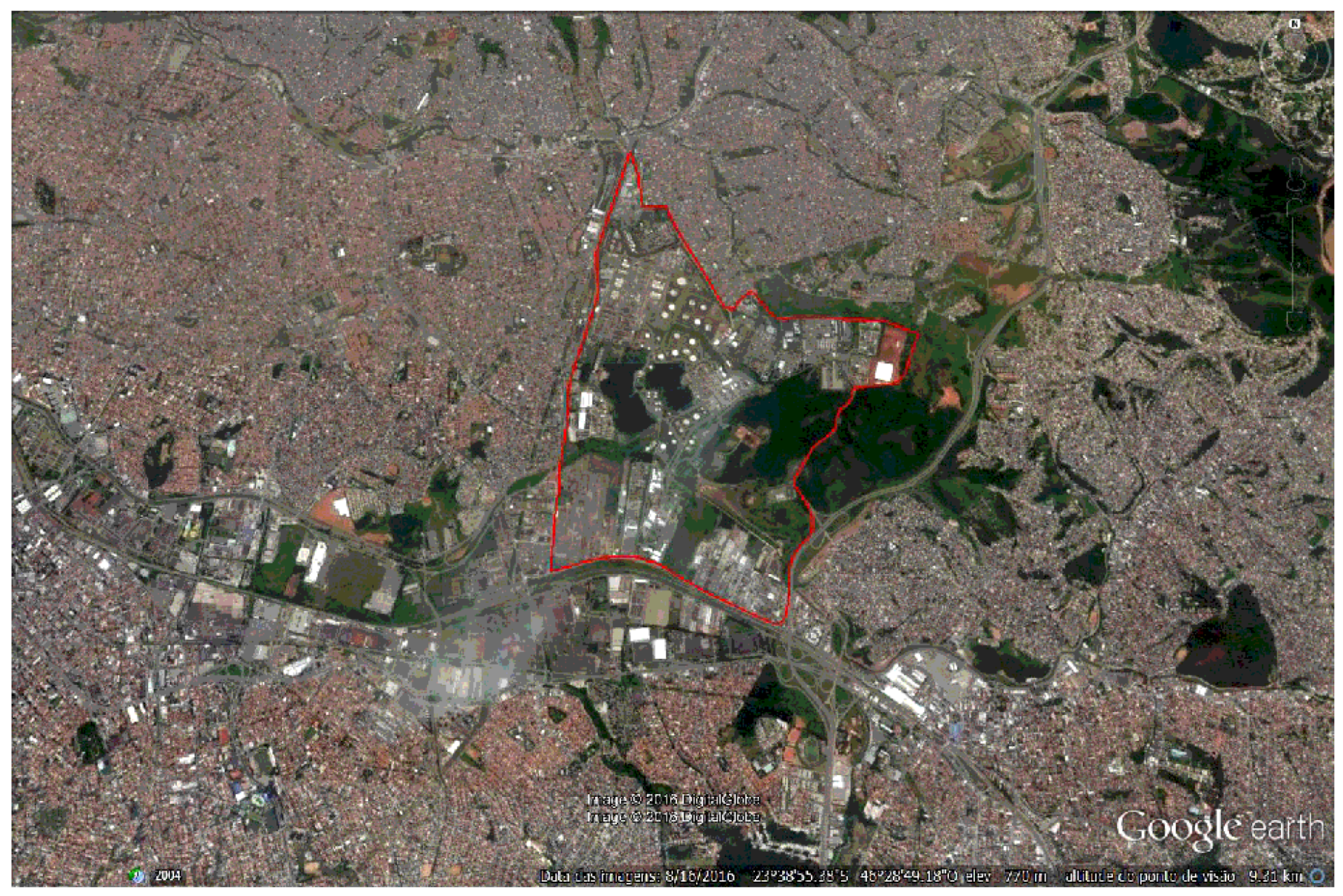

Figure 1

Satellite image showing the Capuava Petrochemical Complex (CPC) area (outlined in red)

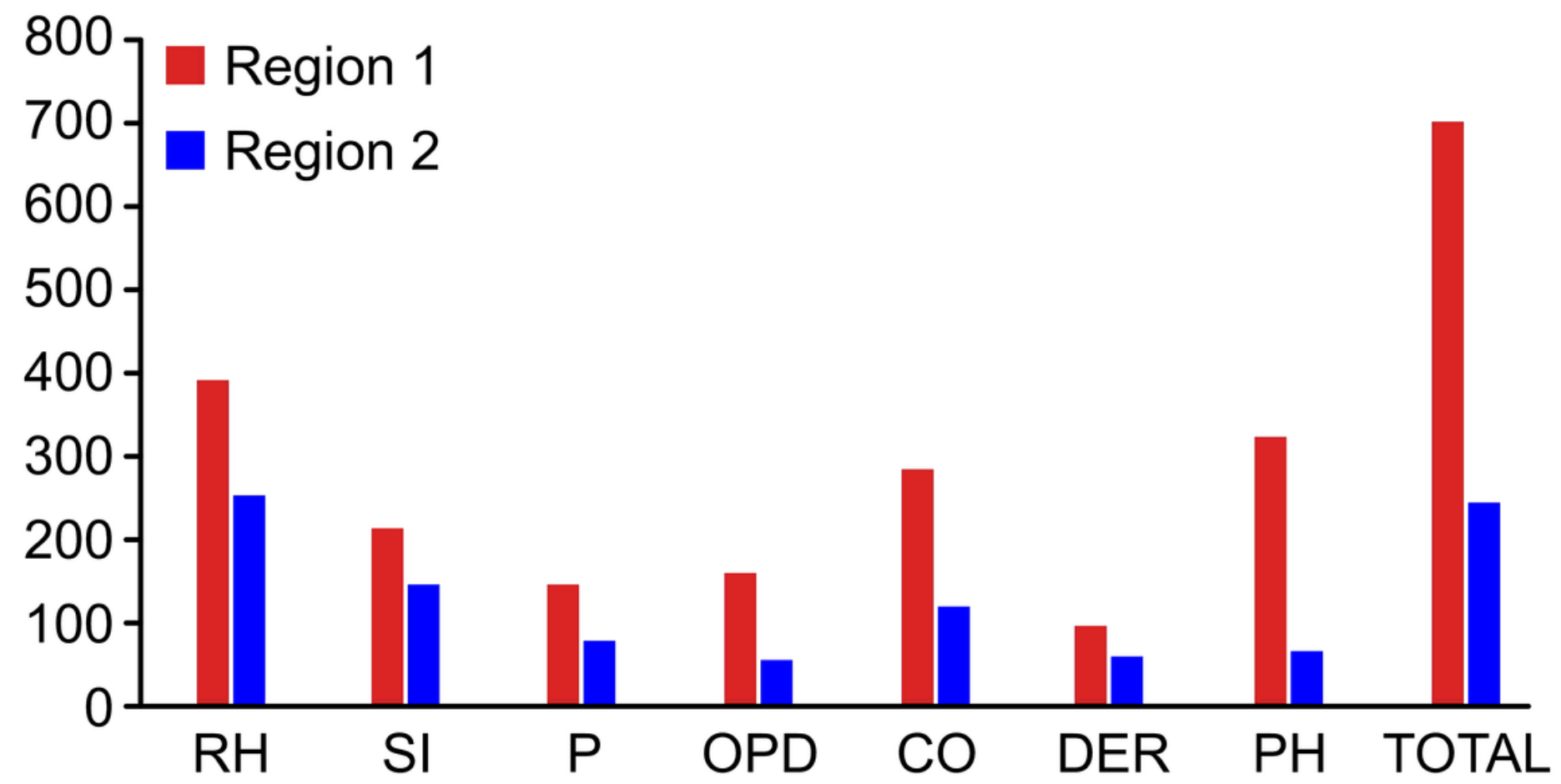


Figure 2

Difference in relative SARS-CoV-2-related complication risk associated with rhinitis $(\mathrm{RH})$, sinusitis (SI), pharyngitis $(P)$, obstructive pulmonary diseases (OPDs), conjunctivitis (CO), dermatitis (DER) and primary hypothyroidism $(\mathrm{PH})$

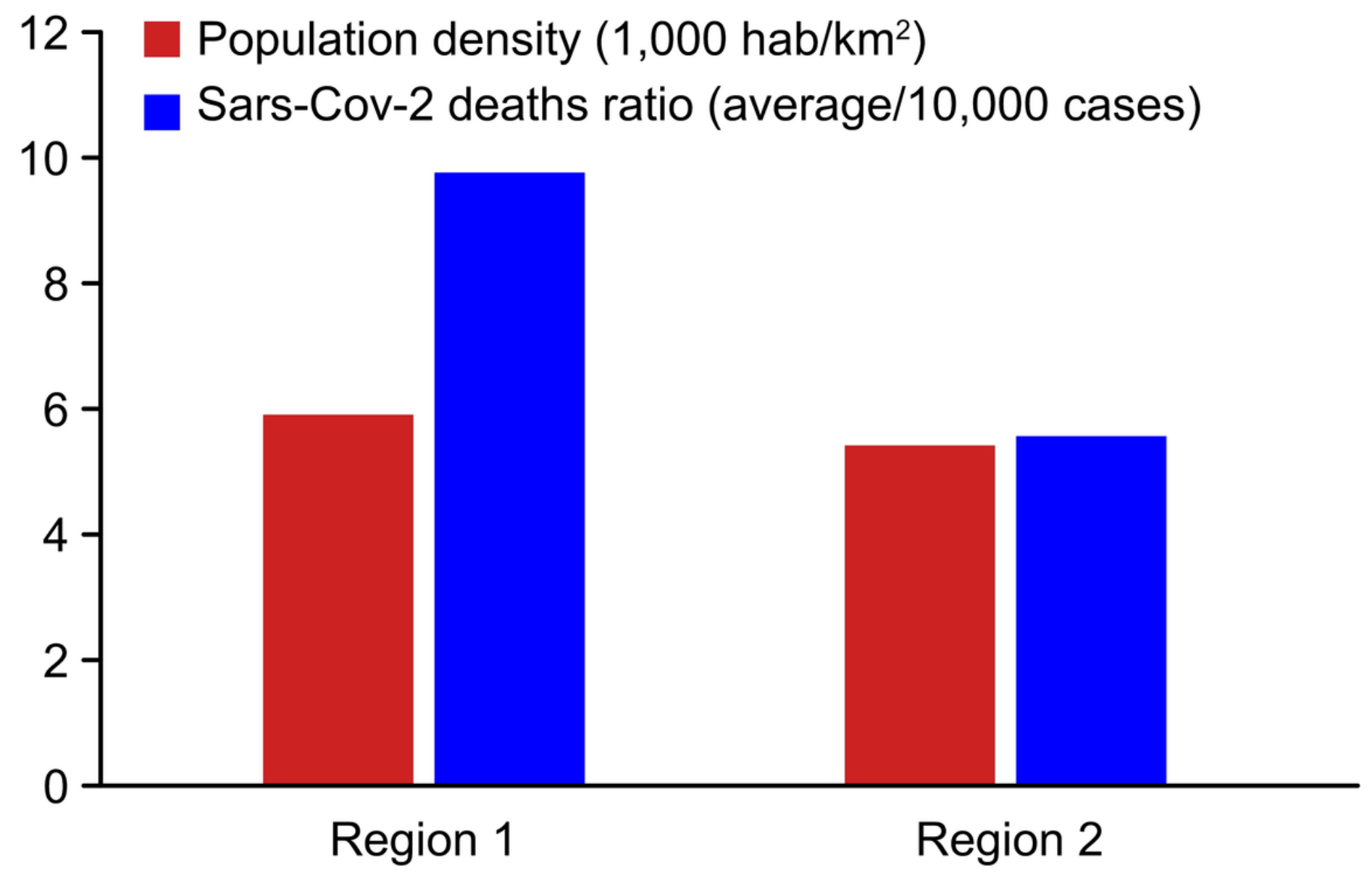

Figure 3

Absolute relation between SARS-CoV-2 deaths and the proximity of each region to the CPC. The regions have similar population densities 